\title{
INDUCTION OF PROTECTIVE IMMUNITY IN CHICKENS IMMUNISED WITH PLASMID DNA ENCODING INFECTIOUS BURSAL DISEASE VIRUS ANTIGENS
}

\author{
I. FODOR ${ }^{1,4^{*}}$, E. HORVÁTH ${ }^{2}$, Nadja FODOR ${ }^{1}$, Edith NAGY ${ }^{2}$, Altancsimeg RENCENDORSH ${ }^{1}$, \\ V. N. VAKHARIA ${ }^{3}$ and S. K. DUBE ${ }^{3}$ \\ ${ }^{1}$ Agricultural Biotechnology Centre, H-2100 Gödöllö, P.O. Box 411, Hungary; \\ ${ }^{2}$ State Institute for Control of Veterinary Biologicals, Drugs and Feeds, \\ H-1475 Budapest, P.O. Box 318, Hungary; ${ }^{3}$ Center for Agricultural Biotechnology, \\ University of Maryland Biotechnology Institute, College Park, Maryland, 20742, USA; \\ ${ }^{4}$ Center for Molecular Biology and Gene Therapy, Loma Linda University School of \\ Medicine, Loma Linda, California, 92354, USA
}

(Received April 8, 1999; accepted June 24, 1999)

Direct DNA inoculations were used to determine the efficacy of gene immunisation of chickens to elicit protective immune responses against infectious bursal disease virus (IBDV). The $v p 2$ gene of IBDV strains GP40 and D78, and the $v p 2-v p 4-v p 3$ encoding segment of strain D78 were cloned in an expression vector which consisted of human cytomegalovirus (HCMV) immediate early enhancer and promoter, adenovirus tripartite leader sequences and SV40 polyadenylation signal. For purification of vaccine-quality plasmid DNA from E. coli, an effective method was developed. Chickens were vaccinated by inoculation of DNA by two routes (intramuscular and intraperitoneal). Two weeks later, chickens were boosted with DNA, and at 2 weeks post-boost, they were challenged with virulent IBDV strain. Low to undetectable levels of IBDV-specific antibodies and no protection were observed with DNA encoding VP2. However, plasmids encoding VP2-VP4-VP3 induced IBDV-specific antibodies and protection in the chickens. DNA immunisation opens a new approach to the development of gene vaccines for chickens against infectious diseases.

Key words: DNA, vaccine, virus, gene expression, antigen

Infectious bursal disease virus (IBDV), the prototype member of the Birnaviridae family, is the causative agent of a highly infectious disease affecting young chickens. All known pathogenic IBDV strains belong to one serotype. The cellular targets for IBDV replication are found in lymphoid organs, mainly in the

\footnotetext{
*Corresponding author: István Fodor, Center for Molecular Biology and Gene Therapy, Loma Linda University School of Medicine, 11085 Campus St., Loma Linda, CA 92354, USA; E-mail: ifodor@som.llu.edu; Fax: 909-478-4177
} 
bursa of Fabricius. There is good evidence to support the notion that actively dividing B lymphocytes are the target cells for the virus (Muller, 1986; Burkhardt and Muller, 1987). Further support comes from the demonstration that in vitro, virus replicates to a high titre in suspensions of pre-B lymphocytes from the bursa, but poorly in lymphocyte suspensions from spleen, lymph nodes or thymus (Fenner et al., 1993). Furthermore, it has also been reported that infection of B lymphocytes in the bursa of Fabricius is cytolytic and leads directly to immunosuppression (Kibenge et al., 1988). Recent reports indicate that cells infected with IBDV undergo apoptosis in vivo and in vitro (Vasconcelos and Lam, 1995; Tham and Moon, 1996), and histopathological lesions in the thymus of IBDV-infected chickens may be due to enhanced endogenous apoptosis of thymic lymphocytes (Tanimura and Sharma, 1998) induced by VP2 (Fernandez-Arias et al., 1997). Immunosuppression increases susceptibility to secondary infectious agents and reduces the growth rate of surviving animals (Lütticken, 1997). The disease affects all major poultry-producing areas worldwide and causes significant losses to the poultry industry. In recent years, the number of IBDV outbreaks with high mortality has been steadily increasing (Brown and Skinner, 1996).

The IBDV genome consists of two segments of double-stranded RNA (dsRNA) (Dobos et al., 1979). The smaller segment (segment B) encodes VP1, the putative dsRNA polymerase, whereas the larger segment (segment A) encodes a $115-\mathrm{kDa}$ precursor polypeptide in a single large open reading frame, which is processed into mature VP2, VP4 and VP3 proteins (Hudson et al., 1986). Segment A also encodes a putative VP5, a 17-kDa protein of unknown function. VP2 and VP3 are the major structural proteins of the virions. VP2 is characterised by significant genetic heterogeneity among IBDV strains (Jackwood and Sommer, 1998), and contains the epitopes responsible for the induction of neutralising antibodies (Becht et al., 1988; Heine et al., 1991). VP3 is considered to be a groupspecific antigen, and VP4 is a protease involved in processing the precursor polyprotein (Jagadish et al., 1988). The complete nucleotide sequence of segment A of a number of strains has been determined (Bayliss et al., 1990; Vakharia et al., 1994; Brown and Skinner, 1996).

Currently, the only practical method for the control of IBDV is the use of vaccines consisting of either inactivated or live attenuated virus. The emergence of new, so-called 'very virulent' variants of IBDV has led to renewing interest in the development of new vaccine strategies. Recombinant IBDV vaccines based on antigen expression in yeast (Macreadie et al., 1990), baculovirus (Pitckovski et al., 1996), adenovirus (Sheppard et al., 1998) and fowlpox virus (Heine and Boyle, 1993) have been reported to provide protective immunity to chickens.

Development of immunisation by direct DNA inoculation has provided a unique method for protection of animals from various infectious diseases such as rabies, malaria, and hepatitis B (see Michel, 1995). Protection of chickens against 
influenza virus (Robinson et al., 1993) and Newcastle disease virus (Sakaguchi et al., 1996) by vaccination with plasmid DNA has opened a new horizon for the development of new generation vaccines for chickens.

We have investigated the protection of chickens against IBDV by a DNA vaccine expressing VP2 antigen or VP2-VP4-VP3 polyprotein precursor. For effective gene expression, the IBDV DNA sequences were placed under the control of a more potent promoter.

\section{Materials and methods}

\section{Cloning of IBDV cDNA}

Both IBDV strains used in this work belong to the classic antigenic group. Purification of the IBDV vaccine strain D78, extraction of viral RNA, reverse transcription, cloning of segment $\mathrm{A}$ and determination of nucleotide sequence of $v p 2-v p 4-v p 3$ polyprotein-encoding sequences have been performed as described (Vakharia et al., 1992; Vakharia et al., 1994). Methods for purification of the IBDV strain GP40 (obtained from Phylaxia-Sanofi, Budapest, Hungary), isolation of viral RNA, cloning and determination of total nucleotide sequence of the $v p 2$ gene will be published elsewhere (manuscript in preparation). Briefly, the GP40 double stranded RNA was denatured and the reverse transcriptase-polymerase chain reaction (RT-PCR) was carried out using a set of forward and reverse primers designed on the basis of known $v p 2$ sequences, and rTth polymerase (Boehringer Mannheim). The PCR fragment of 1,356 bp carrying the $v p 2$ gene was cloned between the $S m a I$ and EcoRI sites of the vector pBluescript II SK (Stratagene) resulting in pBVP17 (not shown). Other cloning procedures were essentially as described (Sambrook et al., 1989).

\section{Plasmids}

The plasmid pWS4 (Sheay et al., 1993) was obtained from Dr. R. Dornburg. The vector contains cytomegalovirus (CMV) immediate early promoter and enhancer, tripartite leader of an adenovirus downstream of the CMV sequences, and SV40 polyadenylation signal. This combination of viral regulatory elements significantly enhanced the foreign gene expression in mammalian cells. A StuISalI DNA fragment $(1.67 \mathrm{~kb})$ containing the $v p 2$ gene of D78 was inserted into pWS4 resulting in pLVP2. Prior to the ligation reaction, the vector was treated with StuI, blunt-ended by T4 DNA polymerase and then treated with SalI. To obtain the expression plasmid pLVP2-4, the blunt-ended StuI-NsiI DNA fragment $(3.22 \mathrm{~kb})$ of strain D78 was inserted into the blunt-ended NotI-PstI sites of pWS4. The construct pLVP5 was derived from the plasmid pLVP2-4 by deleting the redundant DNA segment containing multiple restriction sites (MRS) at the 3'-end 
FODOR et al.

of the IBDV sequences using KpnI, Klenow enzyme and EcoRV. Insertion of the $X b a \mathrm{I}-H i n \mathrm{dIII}$ fragment of pBVP17 carrying the GP40 vp2 gene into the XbaIHindIII sites of pWS4 resulted in pWGP2. Ligation of the SmaI-SalI fragment of pBVP17 into blunt-ended BamHI-SalI sites of pWS4 and subsequent removal of MRS sequences by KpnI and EcoRV resulted in pWV9. The structure of all expression plasmids was verified by DNA sequencing.

\section{DNA purification}

From a freshly streaked plate of E. coli XL1-Blue (Stratagene) transformed with the expression vector, a single colony was picked, inoculated into $5 \mathrm{ml}$ of LB medium containing $50 \mu \mathrm{g} / \mathrm{ml}$ ampicillin, and incubated at $37{ }^{\circ} \mathrm{C}$ overnight. The following day, $2.5 \mathrm{ml}$ of this culture was inoculated into $500 \mathrm{ml} \mathrm{LB}$ medium containing ampicillin and incubated at $37^{\circ} \mathrm{C}$ with vigorous shaking for $12-16 \mathrm{~h}$. The cells were harvested by centrifugation at $6000 \times \mathrm{g}$ for $20 \mathrm{~min}$ at $4{ }^{\circ} \mathrm{C}$, and the cell pellet was resuspended in $5.0 \mathrm{ml}$ of $50 \mathrm{mM}$ Tris- $\mathrm{HCl}$, pH 8.0, $10 \mathrm{mM}$ EDTA. An equal volume $(5 \mathrm{ml})$ of $0.2 \mathrm{~N} \mathrm{NaOH}, 1 \%$ SDS was added to the cell suspension, carefully mixed and left for $30 \mathrm{~min}$ incubation at room temperature. Five $\mathrm{ml}$ of $1.32 \mathrm{M}$ potassium acetate buffer, $\mathrm{pH} 4.8$ was added to the lysate and the mixture was vigorously shaken and centrifuged at $12,000 \times \mathrm{g}$ for $20 \mathrm{~min}$ at room temperature. The supernatant was cleared by allowing to flow through a filter paper, then 0.6 volume of isopropanol was added, the contents mixed well and let stand at room temperature for $5 \mathrm{~min}$ to precipitate nucleic acids. The DNA and RNA in the precipitate were recovered by centrifugation for $15 \mathrm{~min}$ at $12,000 \times \mathrm{g}$ at room temperature and the pellet was dissolved in $2 \mathrm{ml}$ of TE buffer (10 mM Tris, $1 \mathrm{mM}$ EDTA, pH 8.0). RNA was removed by ribonuclease A treatment (Sigma, $10 \mathrm{mg} / \mathrm{ml}$ ) at a final concentration of $75 \mu \mathrm{g} / \mathrm{ml} \mathrm{RNAse}$, incubated for $45 \mathrm{~min}$ at $37^{\circ} \mathrm{C}$. This was followed by addition of a solution of $\mathrm{MgCl}_{2}$ to a final concentration of $0.1 \mathrm{M}$, incubation for $15 \mathrm{~min}$ at $0{ }^{\circ} \mathrm{C}$, and then centrifugation for $10 \mathrm{~min}$ at $12,000 \times \mathrm{g}$ at $4{ }^{\circ} \mathrm{C}$. The supernatant was extracted with an equal volume of phenol and the aqueous phase was removed after centrifugation for $10 \mathrm{~min}$ at $12,000 \times \mathrm{g}$ at room temperature. The phenol phase was treated with 0.5 volume of TE buffer in a similar way and both TE phases containing the DNA were combined, extracted with chloroform/isoamyl alcohol $(24: 1)$ and centrifuged. The upper, aqueous phase was removed, mixed thoroughly with an equal volume of chloroform and centrifuged as described above. This procedure was performed twice. The DNA from the upper phase was then precipitated by adding $3 \mathrm{M}$ sodium acetate buffer, $\mathrm{pH} 5.2$, to a final concentration of $0.3 \mathrm{M}$, followed by addition of 2 volumes of ice-cold ethanol. The contents were mixed well and the tube kept at $-20^{\circ} \mathrm{C}$ for $20 \mathrm{~min}$. The DNA was collected by centrifugation at $12,000 \times \mathrm{g}$ for $10 \mathrm{~min}$ at $0{ }^{\circ} \mathrm{C}$. The DNA pellet was washed through two cycles of centrifugation in cold $70 \% \mathrm{EtOH}$, and dissolved in TE buffer. The DNA was further purified on $\mathrm{CsCl}-\mathrm{EtBr}$ gradients; the $\mathrm{EtBr}$ was removed by multiple 1-butanol ex- 
tractions. After a $2.5 \times$ dilution with sterile $\mathrm{H}_{2} \mathrm{O}$, the DNA was EtOH-precipitated and resuspended in sterile phosphate buffered saline (PBS) for injection. The concentration and purity of each DNA preparation was determined by the OD 260/280 ratio which was in the range of 1.9-2.0.

\section{Animal immunisation and challenge}

In gene vaccination experiments, one day or 3-4 week old, specific pathogen free (SPF) chickens were used. Throughout the experiments, the chickens were maintained in a separate isolation unit. Particularly crucial in this series of experiments was to ensure that the chicks used for vaccination did not have any prior exposure to IBDV and had no antibody titres against IBDV antigens. Chickens (5-25 birds/group) were inoculated with plasmid DNA. The control group of chickens received only the parent plasmid. The inoculation was performed twice with an interval of 14-17 days. Through the experimental period, no birds showed any side effects. Each single immunisation was performed by both intramuscular and intraperitoneal administration of the DNA. On Day 14 or 16 after the boosting inoculation, the challenge experiment was performed by eye-drop, infecting the chickens with $362-1,000$ EID $_{50}$ of virulent IBDV strain CVL 52/70, and blood samples were collected from the animals. Sera obtained from the blood samples were heated to $56{ }^{\circ} \mathrm{C}$ for $30 \mathrm{~min}$ to inactivate non-specific antibodies and analysed for the presence of IBDV-specific antibodies in virus neutralisation (VN) test using primary SPF chicken embryo fibroblast cells and 133-593 $\mathrm{TCID}_{50}$ virulent GP IBDV strain. The chickens surviving the challenge were euthanised and bursae were removed 6 to 9 days post challenge. Protection from bursal disease was evaluated by macroscopic and/or histopathological examination of the bursae.

\section{Results}

For vaccination experiments, highly purified DNA is needed because contaminant bacterial polysaccharides (PLS) may cause serious side effects in immunised animals. To achieve that, most of the conventional methods use either two consecutive runs of $\mathrm{CsCl}$ gradient centrifugation or QIAGEN columns. The first method is time consuming, expensive and causes loss of DNA. The second requires columns that are expensive and vary in reliability. We have developed a new effective plasmid purification procedure (see Materials and methods) which uses only one run of $\mathrm{CsCl}$ gradient centrifugation and allows us to purify plasmid DNA suitable for vaccination, in the range $0.6-6 \mathrm{mg} /$ litre, from $0.5-2$ litres of $E$. coli bacterial culture. The yield of the plasmid mainly depended on the molecular structure since certain plasmids always gave lower yield. This method achieves extensive purification of the DNA from most of the RNA, proteins and PLS at the bacterial crude ex- 
tract stage, and subsequently a single $\mathrm{CsCl}$ gradient ultracentrifugation is sufficient for obtaining highly purified, vaccine-quality DNA. The method is inexpensive and can easily be adopted in any biochemical laboratory. For expression of IBDV proteins, a pWS4 vector was used (Fig. 1). To evaluate the efficacy of gene immunisation with $v p 2$ or $v p 2-v p 4-v p 3$ genes, one-day-old pathogen-free chickens were inoculated with the corresponding plasmid DNA twice with an interval of 17 days. Chicks were divided into four groups and each group was vaccinated with one of the four plasmids, i.e., pWGP2, pLVP2, pLVP2-4 or pWS4. The immunisation was performed by the intramuscular $(50 \mu \mathrm{g})$ and intraperitoneal $(50 \mu \mathrm{g})$ administrations of a total of $100 \mu \mathrm{g}$ DNA per chicken. On Day 14 after the second injection of a total of $100 \mu \mathrm{g}$ DNA (boost), the challenge experiment was performed.

Table 1, Experiment 1 shows that vaccination with the control plasmid pWS4 and pWGP2 produced no measurable antibodies. Only two chickens immunised with pLVP2 were found to show immune response in VN assay, however, the bursa of all immunised chickens showed macroscopic signs of disease after the challenge. Vaccination with pLVP2-4 gave positive results: one out of 7 birds acquired protection against bursal lesions, and four birds had a positive immune response measured in the $\mathrm{VN}$ test. The results of this experiment indicated that for gene vaccination of chickens the plasmid construct pLVP2-4 expressing VP2-VP4-VP3 polyprotein is more effective compared with plasmids (pLVP2, pWGP2) expressing only VP2 antigen.

In the subsequent experiment, vaccine efficacy of the improved construct, pLVP5, expressing VP2-VP4-VP3 polyprotein was evaluated in 4-week-old SPF chickens (Table 1, Experiment 2). Birds received either 15.6 or $150 \mu \mathrm{g}$ DNA by two routes of administration as described above. Nine out of 14 birds (64\%) in the group of chickens injected with $150 \mu \mathrm{g}$ DNA showed antibody response to various extents, and three birds (21\%) of this group were fully protected against viral infection as shown by histopathological examination. In addition, two birds showed signs of partial protection, but one of them, although having developed antibodies of high titre, was found to have mild macroscopic and clear histopathological bursal lesions. Vaccination with $2 \times 15 \mu \mathrm{g}$ DNA was less effective. Eight out of 25 vaccinated birds (32\%) showed antibody response and three of them were protected $(12 \%)$. None of the control birds contained IBDV-specific antibody, nor were any protected against infection.

To improve the efficacy of immunisation, we increased the total amount of gene vaccine to $800 \mu \mathrm{g}$ DNA per bird. In a single immunisation, an intramuscular $(200 \mu \mathrm{g})$ and an intraperitoneal $(200 \mu \mathrm{g})$ administration was performed with a total of $400 \mu \mathrm{g}$ DNA per chicken, and at the boost step, the injection of this amount was repeated. The data presented in Table 1, Experiment 3 show that inoculation of three-week-old SPF chickens with the pLVP5 at Day 14 induced seroconversion in six birds (55\%), four of which (36\%) acquired full protection against virulent IBDV. In control experiments with pWS4 plasmid and PBS, chickens produced no immune response and protection. 

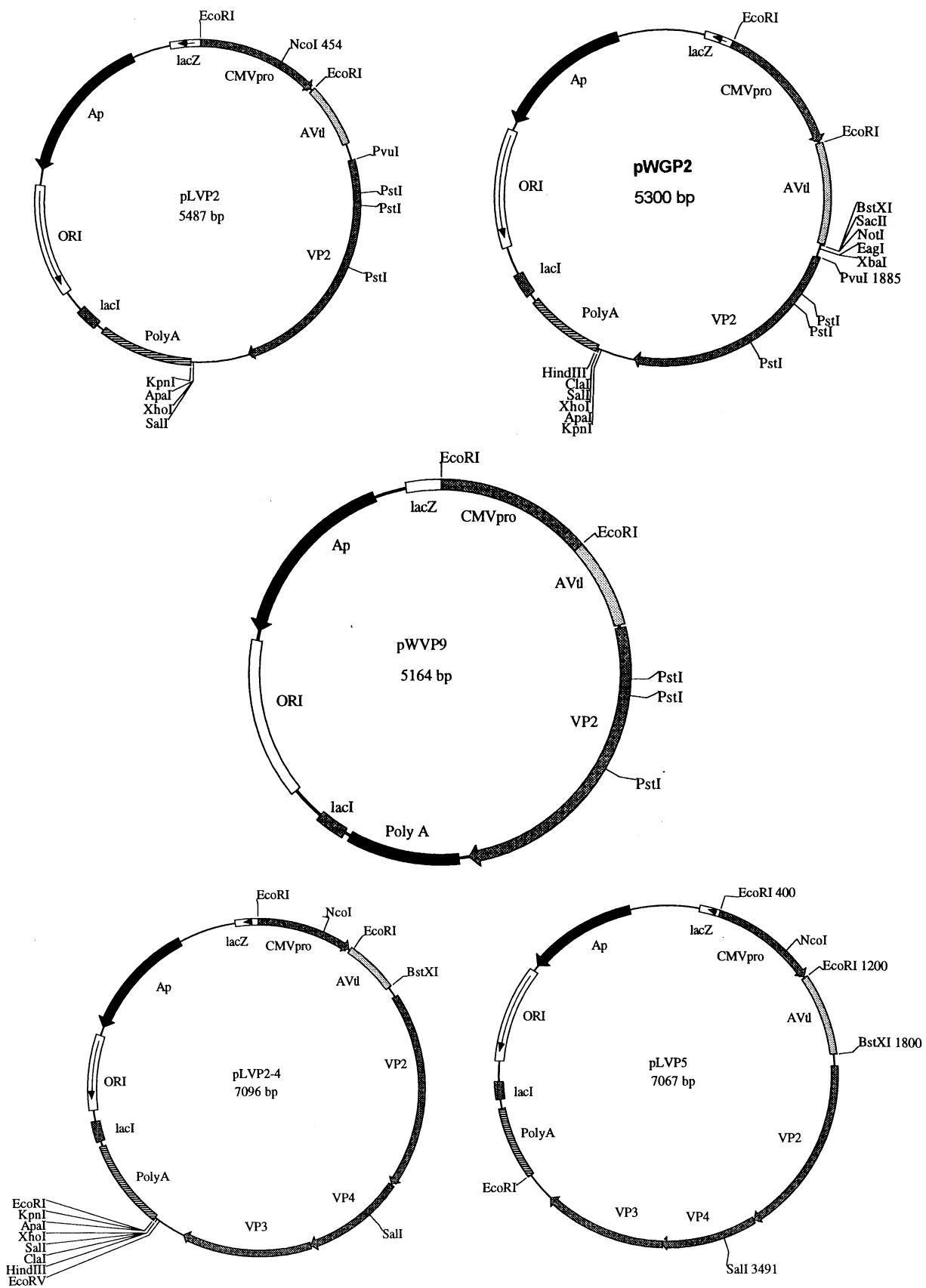

Fig. 1. Maps of expression plasmids. All five plasmids are derived from pWS4 and contain regulatory elements of CMV, adenovirus and SV40. pLVP2, pWGP2 and pWVP9 express VP2; pLVP2-4 and pLVP5 express a VP2-VP4-VP3 polyprotein 
Table 1

Gene vaccination of chickens

\begin{tabular}{|c|c|c|c|c|c|c|}
\hline \multirow[b]{2}{*}{ Plasmid } & \multirow{2}{*}{$\begin{array}{l}\text { Number of } \\
\text { birds }\end{array}$} & \multirow{2}{*}{$\begin{array}{l}\text { DNA/chicken } \\
(\mu \mathrm{g})\end{array}$} & \multicolumn{2}{|c|}{ Bursal lesions } & \multirow{2}{*}{\multicolumn{2}{|c|}{ VN test }} \\
\hline & & & $\begin{array}{c}\text { Macroscopic } \\
\text { pos./neg. }\end{array}$ & Histopath. & & \\
\hline \multicolumn{7}{|l|}{ Experiment $1^{*}$} \\
\hline pSW4 & 11 & 200 & $11 / 0$ & nd & \multicolumn{2}{|c|}{$<1: 4$} \\
\hline pWGP2 & 12 & 200 & $12 / 0$ & nd & \multicolumn{2}{|c|}{$<1: 4$} \\
\hline \multirow[t]{2}{*}{ pLVP2 } & 7 & 200 & $5 / 0$ & nd & \multicolumn{2}{|c|}{$<1: 4$} \\
\hline & & & $2 / 0$ & nd & \multicolumn{2}{|c|}{$1: 22.6,1: 76$} \\
\hline \multirow[t]{3}{*}{ pLVP2-4 } & 7 & 200 & $3 / 0$ & nd & \multirow{3}{*}{\multicolumn{2}{|c|}{$\begin{array}{c}<1: 4 \\
1: 6,1: 64,1: 361 \\
1: 192\end{array}$}} \\
\hline & & & $3 / 0$ & nd & & \\
\hline & & & $0 / 1$ & - & & \\
\hline nv control & 10 & - & $10 / 0$ & nd & \multicolumn{2}{|c|}{$<1: 4$} \\
\hline \multicolumn{7}{|l|}{ Experiment $2^{* *}$} \\
\hline \multirow[t]{4}{*}{ pLVP5 } & 25 & 15.6 & $17 / 0$ & nd & \multirow{2}{*}{\multicolumn{2}{|c|}{$\begin{array}{c}<1: 10 \\
1: 10,1: 15,1: 40 \\
1: 60,1: 80\end{array}$}} \\
\hline & & & $5 / 0$ & nd & & \\
\hline & & & $0 / 2$ & - & \multicolumn{2}{|c|}{$1: 67,1: 160$} \\
\hline & & & $1 \pm$ & - & \multicolumn{2}{|c|}{$1: 2,149$} \\
\hline \multirow[t]{7}{*}{ pLVP5 } & 14 & 150 & $5 / 0$ & nd & \multicolumn{2}{|c|}{$<1: 20$} \\
\hline & & & $2 / 0$ & nd & \multicolumn{2}{|c|}{$1: 20$} \\
\hline & & & $2 / 0$ & + & \multicolumn{2}{|c|}{$1: 30$} \\
\hline & & & $2 / 0$ & - & \multicolumn{2}{|c|}{$1: 190,1: 240$} \\
\hline & & & $0 / 1$ & - & \multicolumn{2}{|c|}{ 1:960 } \\
\hline & & & $1 \pm$ & $1 \pm$ & \multicolumn{2}{|c|}{ 1:960 } \\
\hline & & & $1 \pm$ & + & \multicolumn{2}{|c|}{$1: 1,280$} \\
\hline pWVP9 & 14 & 150 & $14 / 0$ & + & \multicolumn{2}{|c|}{$<1: 10$} \\
\hline nv control & 15 & - & $15 / 0$ & nd & & $1: 2$ \\
\hline Experiment 3 & & & & & & \\
\hline PLVP5 & 11 & 800 & nd & $1-$ & $\leq 1: 2$ & 1:800 \\
\hline & & & & $3+(+/-)$ & $\leq 1: 2$ & $\leq 1: 2$ \\
\hline & & & & $1+$ & $\leq 1: 2$ & $1: 3200$ \\
\hline & & & & $1-$ & $\leq 1: 2$ & $1: 300$ \\
\hline & & & & $1+$ & $1: 16$ & $1: 600$ \\
\hline & & & & $1-$ & $\leq 1: 2$ & $1: 600$ \\
\hline & & & & $1-$ & $1: 24$ & $1: 200$ \\
\hline & & & & $2+$ & $\leq 1: 2$ & $\leq 1: 2$ \\
\hline pWS4 & 5 & 800 & nd & + & $\leq 1: 2$ & $\leq 1: 2$ \\
\hline PBS & 5 & 800 & nd & + & $\leq 1: 2$ & $\leq 1: 2$ \\
\hline
\end{tabular}

*One-day-old chickens were immunised. Challenge experiment was performed on Day 14 after second immunisation, with $1000 \mathrm{EID}_{50}$ of IBDV, strain CVL 52/70. ${ }^{* * *}$ Four-week-old chickens were immunised. The challenge experiment was performed on Day 16 after the second immunisation, with $362 \mathrm{EID}_{50}$ of IBDV, strain CVL52/70. "*** Three-week-old chickens were immunised. VN test was performed on Days 1 and 14 after the second immunisation using 333 TCID $_{50}$ of IBDV. Challenge experiment was performed on Day 16 after the second immunisation, with 1000 EID of IBDV, strain CVL52/70. nv control = non-vaccinated control; nd = not done; $-=$ neg., protection; $+=$ pos., lack of protection; $\pm=$ partial protection 


\section{Discussion}

In this work, we investigated the efficacy of protection induced against infectious bursal disease in chickens by a DNA vaccine. We used the bacterial expression plasmid pWS4 for expression of IBDV genes, since the structural features of this plasmid have been shown to increase the efficiency of gene expression in a mammalian cell line by up to 18 -fold compared to standard CMV-based vectors. For vaccination experiments, we used highly purified DNA to ensure that residual polysaccharide contaminants do not cause serious side effects in the immunised animals. The circular form of plasmid DNA was used in all our experiments since, in contrast to recently published data on chicken vaccinations (Sakaguchi et al., 1996), the immunisation efficacy of the linear form of IBDV DNA was significantly lower (data not shown).

In a separate study, we observed that the combination of intramuscular and intraperitoneal routes of administration produces greater efficacy of gene immunisation (data not shown). Further increase in the efficacy of immunisation has been achieved by a repeat (boost) inoculation with an interval of two weeks, and by the vaccination of three-week-old chickens. The level of gene vaccination efficacy of one-day-old chickens was found to be less effective.

Due to great genetic heterogeneity in the VP2 gene encoding the immunodominant antigen among IBDV strains (Vakharia et al., 1994; Jackwood and Sommer, 1998), we have cloned and sequenced the $v p 2$ gene from strain GP40 (to be published). Surprisingly, neither of the plasmids pWGP2 or pLVP2, expressing GP40 or D78 VP2, respectively, conferred marked immune response and protection in chickens. Relatively low level of synthesized antigen induced by the plasmid in a transient expression system and lack of exposed conformation dependent epitopes may be the explanation for inefficient vaccination with VP2expressing plasmids. However, polyprotein VP2-VP4-VP3 turned out to be a better immunogen (Table 1, Experiment 1). Earlier, it was shown that VP2 was a major host-protective antigen of IBDV and the recombinant VP2 could induce protective immunity in chickens (Bayliss et al., 1991; Heine and Boyle, 1993), although the level of vaccination efficacy (protection in \%) was low. Better VP2mediated protection against mortality and bursal lesions was recently observed in chickens by the use of VP2-expressing recombinant herpesvirus (Darteil et al., 1995) and adenovirus (Sheppard et al., 1998). It is noteworthy that the hostprotective epitopes in VP2 are highly conformation dependent and correct folding is important to generate a protective immune response (Azad et al., 1991). The correct processing of recombinant precursor in chicken cells was shown previously (Heine and Boyle, 1993). It may be that in the cell the freshly cleaved VP2 from the polyprotein VP2-VP4-VP3 has a more optimal conformation of the immunodominant epitopes. Another intriguing possibility is that the polyprotein may 
be enhancing the total antigenic capacity of the input vaccine in an important way, since the two major structural proteins of the virion, VP2 and VP3, resulting from self-processing of the $115 \mathrm{kDa}$ polyprotein, may form virus-like particles of significantly greater immunogenicity than that of the soluble single protein, VP2. In addition, VP3 may have contributed to the immune response of chickens since VP3 is considered to be a group-specific antigen. Using fowlpox virus-vectored VP2-VP4-VP3 polyprotein, other authors failed to demonstrate seroconversion and protection in birds, although the recombinant precursor polypeptide selfprocessed (Heine and Boyle, 1993).

In immunised chickens, direct correlation was found between the titre of IBDV-specific (VP2) antibody and protection, and birds with antibody titres of at least 1:40 to 1:160 in the VN test were protected (Nakamura et al., 1994). In our experiments, all protected birds had elevated titres of IBDV-specific antibodies. However, Table 1, Experiment 2 shows that at low DNA dosage, there is some protection in terms of circulating antibodies, but it is not enough in most instances to prevent bursal lesions. On the other hand, Table 1, Experiment 3 shows that at a high input dosage, there is good protection and bursal lesions are largely prevented. One possibility is that DNA delivery is not efficient enough. Cationic liposome-mediated gene transfer technique (Gao and Huang, 1995) could be an approach to increase the effectiveness of DNA delivery and decrease the amount of DNA vaccine needed for induction of effective protection with DNA of the range of $1-10 \mu \mathrm{g} / \mathrm{bird}$. Recently, this strategy was used for vaccination of birds against Newcastle disease (Sakaguchi et al., 1996). However, some other factors may also play a role, e.g., degradation of input DNA or protein products, so that in Table 1. Experiment 2, not enough antigen concentration was maintained for a sustained effect which could have prevented bursal lesions, while at a high input dosage (Table 1, Experiment 3) a high enough dose of immunogens was available for a longer time. Surprisingly, three chickens, in spite of a high antibody response of the range 1:600 - 1:3,200 (Table 1, Experiments 2 and 3), were not protected from the disease. In this context, additional studies are needed to investigate the role of cellular immune response in protective immunisation against IBD.

Our report is the first demonstration of protection of chickens from infectious bursal disease by a DNA vaccine. The results reported in this paper indicate that DNA vaccination, the efficacy of which has been reported only in avian influenza (Robinson et al., 1993) and Newcastle disease (Sakaguchi et al., 1996), is also applicable for infectious bursal disease of chickens and may have broad application to other avian diseases. 


\section{Acknowledgements}

This work was supported in part under Grant No. HRN-5600-G-00-2055-00, Project 12.103E, Program in Science and Technology Co-operation, Office of the Science Advisor, U. S. Agency for International Development, and by the National Office for Technical Development (OMFB), Hungary.

\section{References}

Azad, A. A., McKern, N. M., Macreadie, I. G., Failla, P., Heine, H-G., Chapman, A. J., Ward, C. W. and Fahey, K. J. (1991): Physiochemical and immunological characterization of recombinant host-protective antigen (VP2) of infectious bursal disease virus. Vaccine 9, 715-722.

Bayliss, C. D., Peters, R. W., Cook, K. A., Reece, R. L., Howes, K., Binns, M. M. and Boursnell, M. E. G. (1991): A recombinant fowlpox virus that expresses the VP2 antigen of infectious bursal disease virus induces protection against mortality caused by the virus. Arch. Virol. 120, 193-205.

Bayliss, C. D., Spies, U., Shaw, K., Peters, R. W., Papageorgiou, A., Muller, H. and Boursnell, M. E. G. (1990): A comparison of the sequences of segment A of four infectious bursal disease virus strains and identification of a variable region in VP2. J. Gen. Virol. 71, 1303-1312.

Becht, H., Muller, H. and Muller, H. K. (1988): Comparative studies on structural and antigenic properties of two serotypes of infectious bursal disease virus. J. Gen. Virol. 69, 631-640.

Brown, M. D. and Skinner, M. A. (1996): Coding sequences of both genome segments of a European 'very virulent' infectious bursal disease virus. Virus Res. 40, 1-15.

Burkhardt, E. and Muller, H. (1987): Susceptibility of chicken blood lymphoblasts and monocytes to infectious bursal disease virus (IBDV). Arch. Virol. 94, 297-303.

Darteil, R., Bublot, M., Laplace, E., Bouquet, J. F., Audonnet, J. C. and Riviere, M. (1995): Herpesvirus of turkey recombinant viruses expressing infectious bursal disease virus (IBDV) VP2 immunogen induce protection against an IBDV virulent challenge in chickens. Virology 211, 481-490.

Dobos, P., Hill, B. J., Hallet, R., Kells, D. T. C., Betch, H. and Teninges, D. T. (1979): Biophysical and biochemical characterization of five animal viruses with bisegmented double-stranded RNA genomes. J. Virol. 32, 593-605.

Fenner, F. J., Paul, E., Gibbs, J., Murphy, F. A., Rott, R., Studdert, M. J. and White, D. O. (1993): Veterinary Virology (second edition). Academic Press, New York. pp. 553-559.

Fernandez-Arias, A., Martinez, S. and Rodriguez, J. F. (1997): The major antigenic protein of infectious bursal disease virus, VP2, is an apoptotic inducer. J. Virol. 71, 8014-8018.

Gao, X. and Huang, L. (1995): Cationic liposome-mediated gene transfer. Gene Therapy 2, 710-722.

Heine, H. G. and Boyle, D. B. (1993): Infectious bursal disease virus structural protein VP2 expressed by a fowlpox virus recombinant confers protection against disease in chickens. Arch. Virol. 131, 277-292.

Heine, H. G., Haritou, M., Failla, P., Fahey, K. and Azad, A. (1991): Sequence analysis and expression of the host-protective immunogen VP2 of a variant strain of infectious bursal disease virus which can circumvent vaccination with standard type I strains. J. Gen. Virol. 72, $1835-1843$

Hudson, P. J., McKern, N. M., Power, B. E. and Azad, A. A. (1986): Genomic structure of the large RNA segment of infectious bursal disease virus. Nucleic Acids Res. 14, 5001-5012. 
Jackwood, D. J. and Sommer, S. E. (1998): Genetic heterogeneity in the VP2 gene of infectious bursal disease viruses detected in commercially reared chickens. Avian Dis. 42, 321-339.

Jagadish, M. N., Staton, V. J., Hudson, P. J. and Azad, A. A. (1988): Birnavirus precursor polyprotein is processed in Escherichia coli by its own virus-encoded polypeptide. J. Virol. 62, $1084-1087$.

Kibenge, F. S. B., Dhillon, A. S. and Russell, R. G. (1988): Biochemistry and immunology of infectious bursal disease virus (review article). J. Gen. Virol. 69, 1757-1775.

Lütticken, D. (1997):Viral diseases of the immune system and strategies to control infectious bursal disease by vaccination. Acta Vet. Hung. 45, 239-249.

Macreadie, I. G., Vaughan, P. R., Chapman, A. J., McKern, N. M., Jagadish, M. N., Heine, H-G., Ward, C. W., Fahey, K. J. and Azad, A. A. (1990): Passive protection against infectious bursal disease virus by viral VP2 expressed in yeast. Vaccine $\mathbf{8}, 549-552$.

Michel, M-L. (1995): DNA-mediated immunization: prospects for hepatitis B vaccination. Res. Virol. 146, 261-265.

Muller, H. (1986): Replication of infectious bursal disease virus in lymphoid cells. Arch. Virol. 87, 191-203.

Nakamura, T., Otaki, Y., Lin, Z., Nunoya, T., Hoshi, S. and Kato, A. (1994): Direct correlation between the titer of infectious bursal disease virus VP2-specific antibody and protection. Avian Dis. 38, 251-255.

Pitckovski, J., Di Castro, D., Shaaltiel, Y., Azriel, A., Gutter, B., Yarkoni, E., Michael, A., Krispel, S. and Levi, B. Z. (1996): Insect-cell-derived VP2 of infectious bursal disease virus confers protection against the disease in chickens. Avian Dis. 40, 753-761.

Robinson, H. L., Hunt, L. A. and Webster, R. G. (1993): Protection against a lethal influenza virus challenge by immunization with a haemagglutinin-expressing plasmid DNA. Vaccine 11, 957-960.

Sakaguchi, M., Nakamura, H., Sonoda, K., Hamada, F. and Hirai, K. (1996): Protection of chickens from Newcastle disease by vaccination with a linear plasmid DNA expressing the F protein of Newcastle disease virus. Vaccine 14, 747-752.

Sambrook, J., Fritsch, E. F. and Maniatis, T. (1989): Molecular Cloning. A Laboratory Manual. Cold Spring Harbor Laboratory, Cold Spring Harbor, Long Island, NY.

Sheay, W., Nelson, S., Martinez, I., Chu, T-H. T., Bhatia, S. and Dornburg, R. (1993): Downstream insertion of the adenovirus tripartite leader sequence enhances expression in universal eukaryotic vectors. Biotechniques 15, 856-862.

Sheppard, M., Werner, W., Tsatas, E., McCoy, R., Prowse, S. and Johnson, M. (1998): Fowl adenovirus recombinant expressing VP2 of infectious bursal disease virus induced protective immunity against bursal disease. Arch. Virol. 143, 915-930.

Tanimura, N. and Sharma, J. M. (1998): In-situ apoptosis in chickens infected with infectious bursal disease virus. J. Comp. Pathol. 118, 15-27.

Tham, K. M. and Moon, C. D. (1996): Apoptosis in cell cultures induced by infectious bursal disease virus following in vitro infection. Avian Dis. 40, 109-113.

Vakharia, V. N., Ahmed, B. and He, J. (1992): Use of polymerase chain reaction for efficient cloning of dsRNA segments of infectious bursal disease virus. Avian Dis. 36, 736-742.

Vakharia, V. N., He, J., Ahmed, B. and Snyder, D. B. (1994): Molecular basis of antigenic variation in infectious bursal disease virus. Virus Res. 31, 256-273.

Vasconcelos, A. C. and Lam, K. M. (1995): Apoptosis in chicken embryos induced by the infectious bursal disease virus. J. Comp. Pathol. 112, 327-338. 